\title{
Celebrity Endorsers in Government Communication: A Plausible Option amidst Uncertainty and Declining Public Trust
}

\author{
http://dx.doi.org/10.25008/jkiski.v6i2.598 \\ Mohamad Alppy Valdez ${ }^{1}$, Rendro Dhani ${ }^{2 *}$ \\ ${ }^{1,2}$ Communication Study in Postgraduate Programme, Institut Komunikasi dan Bisnis LSPR \\ Sudirman Park, Jl. KH. Mas Mansyur Kav. No. 35 Jakarta 10220 - Indonesia \\ *Corresponding author: rendro.d@1spr.edu
}

Submitted: August 1, 2021, Revised: September 2, 2021, Accepted: November 30, 2021

Accredited by Kemristekdikti No. 28/E/KPT/2019

\begin{abstract}
This paper examines the harness of celebrity endorsers by government organizations as a strategy of political public relations. The purpose of this study was to broaden understanding of how celebrity endorsers and key opinion leaders work in the political realm, notably in supporting government policy. This descriptive-qualitative research uses a single case study on the promulgate efforts of the government's COVID-19 vaccination program using celebrity endorsements. Literature research and social media material from a celebrity endorser were used as data collection techniques. To discover propaganda techniques, content analysis was performed on Raffi Ahmad's social media posts. Next, a group discussion with six key informants was held to confirm the findings. Given the context and focus of this study lies on government organizations, we offer a different approach in examining celebrity endorsements by using propaganda theories and concepts. Kahneman's dual-system theory of fast and slow thinking was also fruitful to rationalize the work of endorsement and relevant to propaganda and other persuasion theories. We found that the key messages that Raffi Ahmad published on his social media contained propaganda elements that had the potential to influence public opinion before making a decision. Therefore, the use of celebrity endorsements by government organizations is likely to be effective in influencing public behavior, or at least in raising awareness of government policies. We conclude that celebrity endorsement can be a plausible option to be implemented in the government communication strategy to achieve certain objectives.
\end{abstract}

Keywords: Celebrity endorsers; President Jokowi; political public relations; propaganda; government communication.

\section{Introduction}

Raffi Ahmad is a well-known Indonesian celebrity and young entrepreneur who has the most popular social media accounts in terms of followers and subscribers. As of November 2021, Ahmad already has 56.6 million Instagram followers (@raffinagita1717), a figure that other celebrities are unlikely to match, not to mention his YouTube channel (Rans Entertainment), which has 22 million subscribers. Although many research featuring Raffi Ahmad showed that his endorsement is effective in influencing consumer behavior and purchase intentions (Ayuni \& Prasetyawati, 2020), others found that endorser credibility (featuring Raffi Ahmad) only had a positive impact on brand credibility, but not on brand equity or purchase intention (Agustiansyah \& Mardhiyah, 2020). 
Celebrity endorsement is an old practice in marketing and advertising that is gaining popularity these days (Aljasir, 2019; Enke \& Borchers, 2019; Mookda et. al., 2020; O'Regan, 2014; Penney, 2018). Despite their greater visibility, celebrities have been neglected in the public relations discipline (Davies \& Hobbs 2020; Fitch, 2017). In Indonesia, political elites have started to use celebrity endorsers just in the last two decades as a political marketing tool to enhance their political campaigns. Indonesia's sixth president, Susilo Bambang Yudhoyono, is probably the first political elite in the country to employ well-known celebrities in his political public relations or 'soft propaganda' strategy during his administration. He wrote songs which were later sung by famous singers to boost his political beliefs and build his positive image (Dhani, 2018).

As a starting point, this paper needs to underline that according to Reuters Institute, online news and social media are increasingly important in their role as the largest vehicle and source of information in Indonesia (Pusparisa \& Mutia, 2018). As of January 2021, 202.6 million individuals were online with penetration rates stood at 73,7 percent (Kemp, 2021). At the same time, 170 million individuals, or 61.8 percent of the Indonesian population, actively used social media (Kemp, 2021). The younger generation has contributed to the rapid growth of netizens in Indonesia. They are Generation Z (born between 19972012) with a total of 74.93 million people and Millennials (born between 1981-1996) with 69.38 million people (Badan Pusat Statistik, 2021). Inevitably, these people seek out social media influencers for guidance before making decision. The corporate sector has long worked with influencers to increase their visibility and hence, their market share. These facts are the rationale why government institutions are interested in embracing social media influencers in their political public relations strategies. As such, President Joko Widodo (Jokowi) interested in employing celebrity endorsers in his government communications. $\mathrm{He}$ recruited celebrity endorsers with the agenda of influencing public disapproval of certain government policies that are expected to support them eventually.

Moreover, the strategic communication of Jokowi administration often received public criticism during the pre-COVID-19 crisis (late January to early March 2020). This was exacerbated by a series of statements, denials, and wishful thinking from the government officials (Farisa \& Galih, 2020). The authorities even deliberately withheld some information about COVID-19 cases to keep the public from panicking (Pangestika, 2020). Therefore, the public and mass media expressed their concern over the lack of government strategic communication in dealing with COVID-19 (Bayuni, 2020).

Nevertheless, the recruitment of celebrity endorsement has lately become public concern given that employing these influencers cost a lot of money. The news media, netizens, and even legislators questioned the government's decision to spend the state budget to pay influencers. Fadli Zon, a politician from Greater Indonesia Movement (Gerindra), for example, criticized the government's spending of IDR 72 billion for influencer services and media campaigns to stimulate tourism as an amateur communication strategy (Sari \& Meiliana, 2020). According to Indonesian Corruption Watch (ICW), the government has spent IDR 1.29 trillion from 2014 to 2020 on digital activities. ICW researcher Egi Primayogha revealed that the money was used to build infrastructure to support digital media activities, including to compensate influencers (Ramadhan \& Meiliana, 2020).

Some previous studies claimed that the Indonesian government did not build a wellintegrated communication system between national and local governments in order to battle the COVID-19 outbreak. Setiawana et al. (2021), for instance, stated that the government was not fully prepared to interact with the public and there is no coordinated effort between the central government and local governments in conveying information and policies related to handling the pandemic. Others have noticed inconsistencies in government communication among officials, due to the fact that each government official had various concerns about the issues raised in the communication and coordination in handling COVID-19, notably between President Jokowi and the Jakarta governor (Salahudin et al., 2020; Windarsih, 2020). In contrast, Nabila (2021) in her study concluded that Indonesia COVID-19 Task Force, one of government agency that deals with the COVID-19, was effective in generating a community perception that the government managed COVID-19 properly and they did not scare the public with bad news about COVID-19. Whilst, Ahmad (2021) examined presidential rhetoric of Jokowi from the Aristotelian rhetorical leadership models as one of persuasive strategies with the etho-logo, 
and patho-centric. However, we hardly found any research that focused on celebrity endorsers who promoted government policy, especially in the areas of propaganda and political public relations strategies. This paper is intended to fill this gap.

Following the global commercialization of vaccines, President Jokowi was keen to get millions of doses of vaccines and asked his ministries to handle the distribution of COVID19 vaccines around the country. The problem is, there have been countless rejections from politicians, pundits, artists, celebrities, and other opinion leaders. News about vaccination declared haram (forbidden by Islamic law) for Muslims, vaccines that may cause serious ill effects or even death, and vaccine ineffectiveness are all instances of bad information spreading across society. This ambiguous and perplexing information leaves the public in limbo, thus fostering doubt and undermining public trust and government legitimacy (Riefky, et al., 2021). Amidst this situation, President Jokowi arranged the execution of the first vaccination scheduled for January 13, 2021 at Merdeka Palace, Jakarta. $\mathrm{He}$ appointed five new spokespersons to socialize the COVID-19 vaccination. The government also invited celebrity endorsers to escort the president in the first dose of vaccination, which was widely covered and broadcast by the news media.

\section{Theoretical Framework}

McCracken's meaning transfer model is one of frequently used theory in celebrity endorsement study. Schimmelpfennig and Hunt (2019) explored and found substantial evidence for four main supporting theories that are often used to analyze celebrity endorsers: source credibility, source attractiveness, fit hypothesis, and meaning transfer model. According to Schimmelpfennig and Hunt, each theory is an efficient construct for a certain set of endorsements, but no one theory can explain celebrity endorsements holistically. They argue: "Only a comprehensive framework comprising all theories can explain the great variety of different celebrity endorsements executed in advertising praxis".

From a strategic communication perspective, Enke and Borchers (2019) define social media influencers as "third-party actors who have established a significant number of relevant relationships with a specific quality to and influence on organizational stakeholders through content production, content distribution, interaction, and personal appearance on the social web". The functions performed by the influencers for organizations have historically been performed by a variety of different actors with whom companies also collaborate. Enke and Borchers identify at least five distinct players whose roles of social media influencers can complement or even supersede, namely "creative agencies, advertising media, journalistic media, testimonial givers, and opinion leaders". Likewise, McCracken (1989) defines celebrity endorser as, "any individual who enjoys public recognition and who uses this recognition on behalf of a consumer good by appearing with it in an advertisement". McCracken said further that the scope is intentionally broad to include not just traditional movie and television stars, but also athletes, politicians, business leaders, artists, and military personnel.

Given that the subject of this work is celebrity endorsement used by government organizations, this paper attempts to develop the study of celebrity endorsement from a different perspective, namely propaganda and political public relations strategies. To begin, the terms 'political public relations', government communication', and 'propaganda' must be defined to avoid confusions concerning about some of the topics explored in this article. Political public relations, as defined by Strömbäck and Kiousis (2020), is "the management process by which an actor for political purposes, through communication and action, seeks to influence and to establish, build, and maintain beneficial relationships and reputations with key publics and stakeholders to help support its mission and achieve its goals". Based on this definition, we consider that celebrity endorsements used by government organizations are part of political public relations which in practice can be associated with political propaganda.

Meanwhile, Canel and Sanders (2012, cited in Sanders, 2020) defined government communication as follows:

The area of practice and study of that usually managed communication directed to key publics and pursuing both political and civic purposes, carried out by executive politicians and officials working for public institutions with a political rationale. These institutions are constituted on the basis of citizens indirect or direct consent and are charged to enact their will (Canel and Sanders 2012). 
Sanders noted further that the definition of government communication is more narrowly drawn, focused on executive communication, and more broadly characterized as aiming not only political but also civic ends. Nonetheless, she added, "it would be naïve to believe that government communication can pursue civic goals in a way fully divorced from its specific structural contingencies, which include the political environment in which it operates" (Sanders, 2020).

Propaganda, on the other hand, is addressed here as Jowett and O'Donnell (2015) defined, "the deliberate, systematic attempt to shape perceptions, manipulate cognitions, and direct behavior to achieve a response that furthers the desired intent of the propagandist". They explained that the propagandist's information may look unarguable and completely factual. Also, the propagandist will seek to control information flow and manage a certain public's attitude by forming perceptions using informative communication tactics (Jowett \& O'Donnell, 2015). One of the differences between the two concepts is their intention of influencing the audience. In public relations, they attempted to foster mutual understanding, but in propaganda, the common understanding was not prioritized. Emotional language and presentations are also related with propaganda. Although this is occasionally true, many agents think that objective reporting is more effective (Jowett \& O'Donnell, 2015). Following Jowett and O'Donnell $(1992,2015)$ work on propaganda typology, which classifies propaganda based on three categories, i.e. white, gray and black propaganda, Moloney (2006) argues that public relations is a 'grey' propaganda that lies between black and white areas and he calls it as 'weak' propaganda. Correspondingly, Dhani (2018), contends that the phrase 'political public relations' may well be understood as 'soft propaganda,' as it is clearly used propaganda technique but it was done in sophisticated and subtle ways. In the context of influencing public opinion, Moloney (2006) claims that, "If governments could propagandise successfully in wartime, they and other interests could do the same in peacetime". We are in line with this premise and thus argue that if celebrity endorsements can work effectively in marketing and advertising, they can also work effectively in political public relations.

In the second issue of a monthly bulletin of Propaganda Analysis, it was released the infamous seven common devices. "We can more easily recognize propaganda when we see it if we are familiar with the seven common propaganda devices" (How to Detect Propaganda, 1937) as follows: (1) NameCalling. Giving an idea a bad label and therefore rejecting and condemning it without examining the evidence; (2) Glittering Generality. Associating something with a "virtue word" and creating acceptance and approval without examination of the evidence; (3) Transfer. Carries the respect and authority of something respected to something else to make the latter accepted. Also works with something that is disrespected to make the latter rejected; (4) Testimonial. Consists in having some respected or hated person say that a given idea or program, product, or person is good or bad; (5) Plain Folks. The method by which a speaker attempts to convince the audience that he or she and his or her ideas are good because they are "of the people," the "plain folks"; (6) Card Stacking. Involves the selection and use of facts or falsehoods, illustrations or distractions, and logical or illogical statements to give the best or the worst possible case for an idea, program, person, or product; (7) Bandwagon. Has as its theme "everybody - at least all of us - is doing it!" and thereby tries to convince the members of a group that their peers are accepting the program and that we should all jump on the bandwagon rather than be left out (How to Detect Propaganda, 1937, cited in Jowett \& O'Donnell, 2015).

The seven propaganda tools above were used in this paper as a guide to detect propaganda contained in images, videos, and words used by Raffi Ahmad in his social media content. Furthermore, an overview of the propaganda process is described by Jowett and O'Donnell (2015) to show how propaganda works in modern society. 


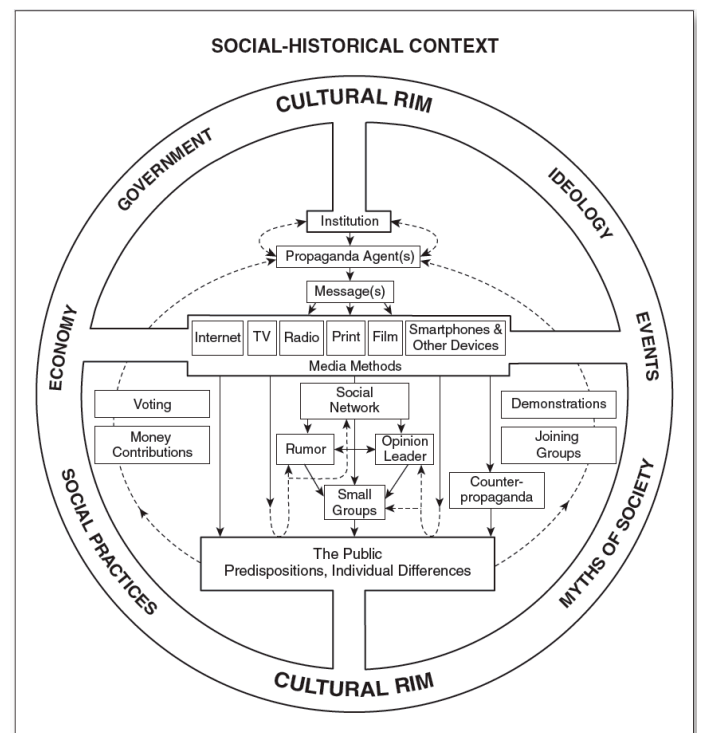

Figure 1. Model of the process of propaganda.

Source: Jowett \& O’Donnell, 2015.

Figure 1 above shows that propaganda is a complex process and is increasingly complicated in the modern era because of many elements that may affect its effectiveness. Drawing on a socio-historical context, Jowett and O'Donnell argue that propaganda is a form of communication and therefore can be described as a process. They maintain, "A model of the propaganda process includes a socio-historical context, a cultural circle consisting of government, economy, events, ideology, and myths of society; institutions; propaganda agency; media method; social network; and the public" (Jowett \& O'Donnell, 2015).

Despite the complexity of propaganda and other persuasive communication techniques, this paper also draws on the dualsystem theory of fast and slow thinking, posited by Daniel Kahneman. We used the theory as a relevant approach that can help explain how celebrity endorsements and propaganda work. The dual-process and dual-system theories are basically empirical theories of human psychology (Frankish, 2010) that have often been used previously to understand how individuals struggle with cognitive tasks before reaching a decision (Viswanathan \& Jain, 2013). Kahneman (2011) explained that cognitive activities have two separate processing modes, so-called System 1 (refers to fast thinking) and System 2 (refers to slow thinking).

According to Kahneman, "System 1 operates automatically and quickly, with little or no effort and no voluntary control" (p. 20). The theorist suggests that when faced with difficult decisions, individuals often use intuitiveness and resemblance as a simplifying heuristic (System 1), but the dependency heuristics produce predictable bias (systematic error) in their estimates. However, Kahneman added, that is not the only way the mind works. There is another system that is 'lazy' but works in more detail, namely System 2, or a system that "allocates attention to mental activities that demand it, including complex computations. The operation of System 2 is often associated with subjective experiences of agency, choice, and concentration". Kahneman maintains:

When System 1 runs into difficulty, it calls on System 2 to support more detailed and specific processing that may solve the problem of the moment. System 2 is mobilized when a question arises for which System 1does not offer an answer, as probably happened to you when you encountered the multiplication problem (Kahneman, 2011).

The effectiveness of celebrity endorsement and propaganda, therefore, can be estimated, planned, and rationalized given that human nature is based on the above theory. In addition, the attractiveness of celebrity endorsers and key opinion leaders is also an important factor in this context. For example, if one enjoys a public figure or the president's voice and looks, he/she may like his politics. Kahneman (2011) added that the 'halo effect' refers to the tendency to like (or dislike) everything about a person, including unnoticed characteristics. He continues: 
When the handsome and confident speaker bounds onto the stage, for example, you can anticipate that the audience will judge his comments more favorably than he deserves. The availability of a diagnostic label for this bias - the halo effect-makes it easier to anticipate, recognize, and understand (Kahneman, 2011).

In brief, Kahneman (2011) argues that a spontaneous search for an intuitive solution may fail when neither an expert solution nor a heuristic response is available. In such cases, we often find ourselves turning to a slower, more deliberate, and effortful form of thinking. This is called as slow thinking. Fast thinking includes both expert and heuristic versions of intuitive cognition, as well as fully automated mental functions of perception and memory.

Within this framework, this paper seeks to expand on the study of celebrity endorsement from a different angle, notably propaganda and political public relations approach which can show the marvels and the flaws of intuitive thought.

\section{Material and Methodology}

This study uses a qualitative approach with a single case study to critically examine a strategic government communication. Celebrity endorsements of government policy related to the COVID-19 vaccination program was chosen as a case study. We applied in-depth literature review, browsing on social media content, and focus group discussions (FGD) as data collection techniques to evaluate this case.

According to Leedy \& Ormrod (2021) a case study may be used to examine how an individual or program changes over time as a consequence of certain events or conditions.
The case study is also most useful for developing or giving preliminary evidence for tentative explanations about the events being investigated.

In accordance with the established research design, this study collects and critically analyzes social media content that shows the first and second dose of COVID-19 vaccination at the Merdeka Palace on January 13, 2021 (first dose) and January 27, 2021. We limit and focus the content on this national public health program, which is endorsed by Raffi Ahmad on his YouTube official channel [Rans Entertainment], and his official Instagram account [@raffinagita1717].

Next, a list of questions, a time schedule, and themes to be discussed in accordance with the study goals for a group discussion were developed. Group discussion is a way of acquiring qualitative data that involves a small group of individuals participating in an informal group chat (or talks) about a certain topic or set of themes. It also allows for more spontaneous replies and provide a forum where the participants can discuss personal problems and offer possible solutions. We identified and carefully selected six participants as key informants. This number, according to Krueger and Casey (2000), is adequate, as it is generally accepted that between six and eight participants are sufficient for group discussions. We organized the FGD in early May 2021, with semi-structured interviews lasting for almost two hours utilizing the G-meet platform. All conversations in the interviews were conducted in Indonesian, and we transcribed verbatim from the video recording before translating it for data coding.

\section{Result and Discussion \\ Social Media Content Analysis}

Table 1. Some propaganda techniques detected in Raffi Ahmad's Instagram \& YouTube official account

\begin{tabular}{|l|l|l|}
\hline Figures \& Sources & Titles, Captions (translated) & $\begin{array}{l}\text { Propaganda } \\
\text { Devices }\end{array}$ \\
\hline & $\begin{array}{l}\text { Bismillah [ [In the name of Allah] } \\
\text { [Instagram/Photograph } \\
\text { @raffinagita1717]. }\end{array}$ & $\begin{array}{l}\text { Transfer, } \\
\text { Glittering } \\
\text { Generality }\end{array}$ \\
\hline \\
\hline Figure 2. Ahmad, 2021a.
\end{tabular}




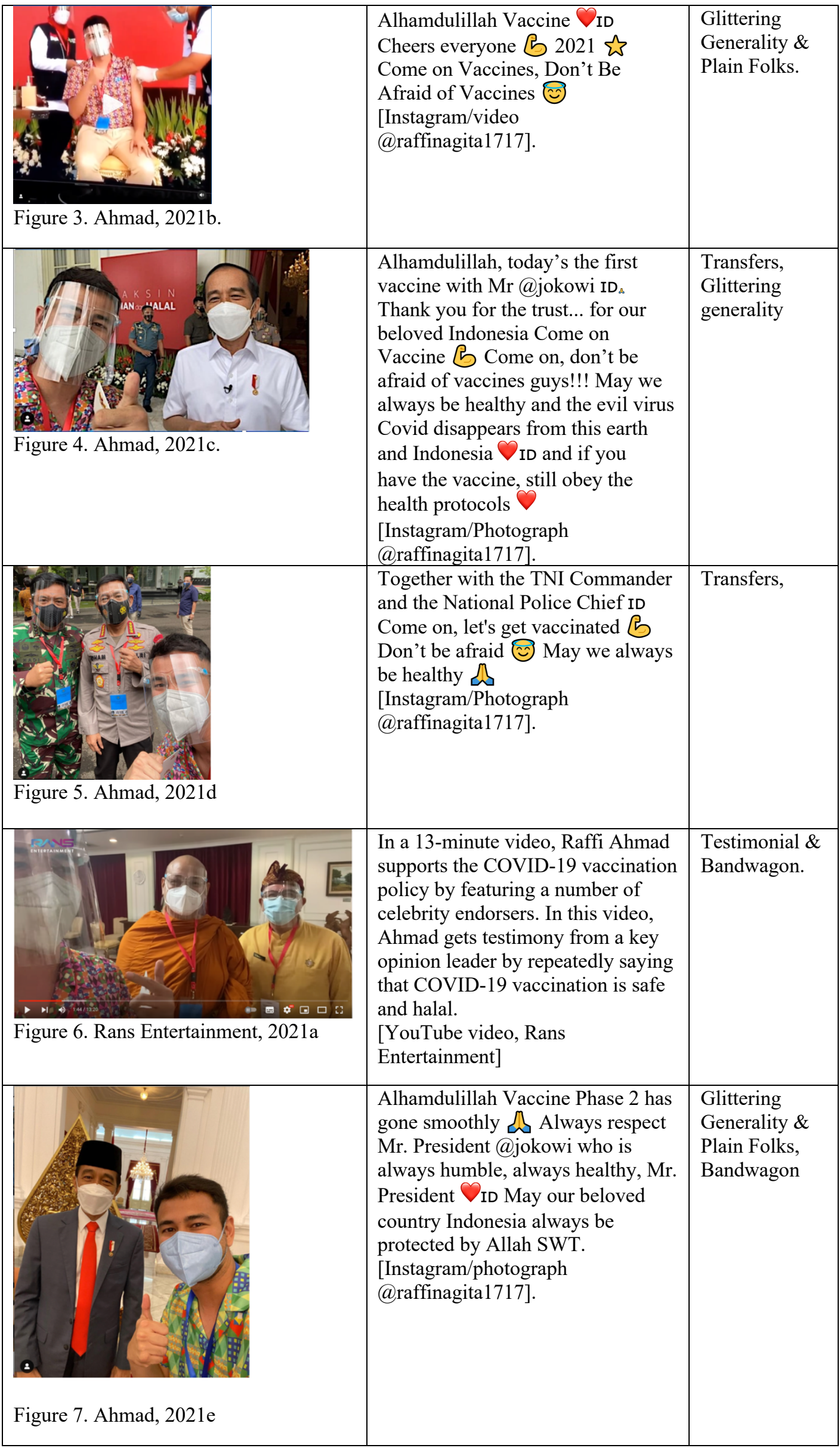




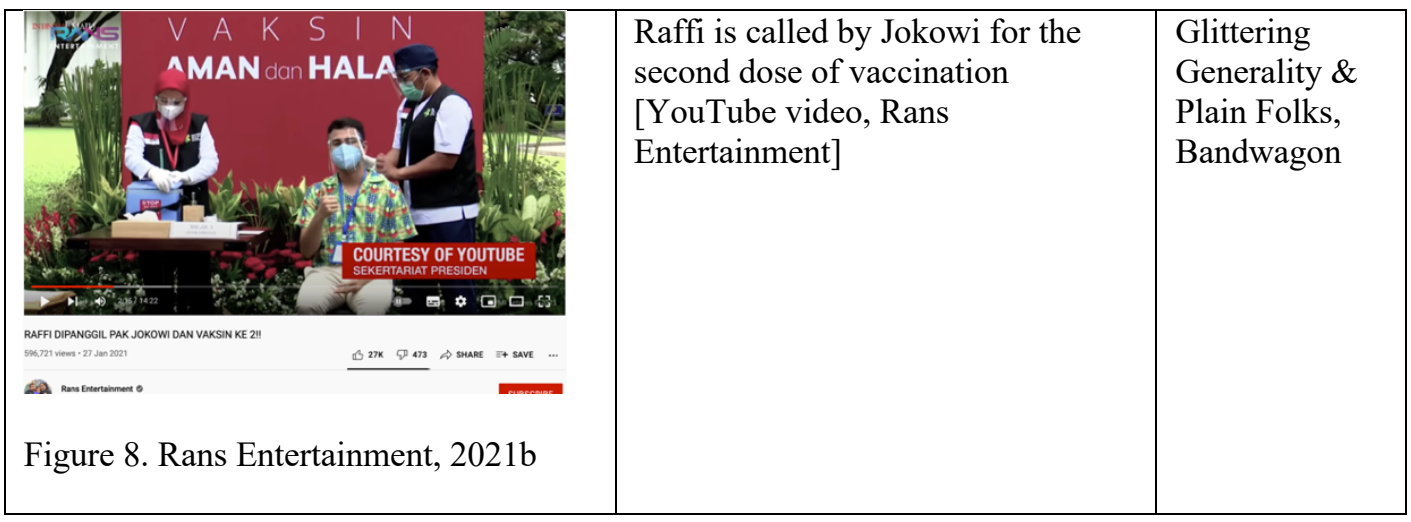

As shown in Table 1, specifically Figure 2, Ahmad shows an invitation from the President to get the first jab of the vaccine with a caption Bismillah [with a love emoticon]. The propaganda techniques contained in this content are Transfer (of authority, from the president's invitation to Ahmad), which shows Ahmad's credibility, and Glittering Generality by using the word Bismillah (in the name of Allah), which shows a religious character. Next, a video posted on Instagram (Figure 3), Ahmad shows himself getting a COVID-19 vaccine and invites millennials and the Indonesian people to be brave and get vaccinated too. In the video, Ahmad uses the word Alhamdulillah (Thanks God) and Don't Be Afraid, which is a glittering generality, and it is stated that Ahmad represents the millennial group because he is also part of and hence, just like them (plain folks).

The next two pictures posted on Instagram are Ahmad takes picture together with President Jokowi (Figure 4) and with the TNI Commander and the National Police Chief (Figure 5). In these two Instagram posts, Ahmad again uses the Transfers (gaining the authority from the key opinion leaders, President Jokowi, TNI Commander and Police Chief to Ahmad), and Glittering Generality on the two image captions namely, "Alhamdulillah", "thank you for the trust", "our beloved Indonesia", "don't be afraid"), and words in the backdrop: "Vaksin Aman dan Halal" [Vaccine is Safe and Halal].

In another post on YouTube channel (Figure 6), Ahmad filmed himself with various key opinion leaders who also received the first dose of the COVID-19 vaccine. Several people who were asked for their opinion commented on supporting this vaccination program which aims to convince and influence the followers of each key opinion leader with their testimonies. We detect two propaganda techniques in this post: Testimonial and Bandwagon. The latter technique asks the public at large and their followers to also dare to get vaccinated because "everybody — at least all of us - is doing it!" Hence, they must also be vaccinated or left alone [Bandwagon technique]. Two weeks after the first dose of vaccination, Raffi Ahmad and key opinion leaders were again invited by the government to get the second jab of COVID-19 vaccine. Ahmad re-posted the event on his social media, but not as massively as the first vaccination. In this second vaccination, Ahmad only uploaded two posts, one on his Instagram account and the other on his YouTube channel (Figure $7 \& 8$ ). Unlike the previous post on the first vaccination event, on the second vaccination opportunity, Ahmad did not provide much time and place to endorse the COVID-19 vaccination as a public health program.

From social media content analysis, our findings suggest that at least five propaganda techniques were utilized in the content published to Raffi Ahmad's Instagram account and YouTube channel. In these messages, we found five types of propaganda: Glittering Generality, Transfer, Plain Folks, Testimonials, and Bandwagon. These strategies are part of a set of seven prominent propaganda techniques employed by both individual actors and governmental institutions (How to Detect Propaganda, 1937). In the first dose of COVID19 vaccination on January 13, 2021, we found four posts (three photograph and one video) on Ahmad's Instagram account and one video content on his YouTube channel.

The key messages that the endorser and key opinion leaders said repeatedly are: Don't' be afraid! Vaccine is safe! Allah [God] will protect us! Vaccine is Safe and Halal. The idea behind using suggestion or stimulation as a propaganda tool is that it will induce the public to accept the claim even if there is no logical reason to do so. Since the propagandist usually tries to avoid critical answers from his audience, suggestion is one of his most important tactics. 
This effort is a framing technique that aims to counter negative opinions and public doubts about the COVID-19 vaccine which is said to be dangerous and haram (forbidden under Islamic law).

Therefore, by involving endorsers and key opinion leaders in encouraging and influencing the public, the government communication strategy has the capacity and great potential to affect public attitudes and opinions. In the case of the COVID-19 vaccination program, Kahneman's dual-system theory explains that when faced with tough decisions, individuals tend to choose system 1 (fast-thinking) to make a decision. The endorser's function in this scenario is to convince people to do what the message producer desires. Correspondingly, as an endorser, Ahmad uses several propaganda techniques and his messages are also conveyed in several posts on social media. Hence, the effectiveness of propaganda can be maximized based on propaganda and dual-system theories.
Finally, Ahmad also has extraordinary charm and it was proven that he was able to capture more than 78 million followers and subscribers on social media. According to the 'halo effect' theory, there is a tendency that the attractiveness of endorsers can lead the public to like everything about the endorser, including their character and message (Kahneman, 2011).

\section{Focus Group Discussion Analysis}

After organizing a two-hour group discussion, we found varied insights and perspectives from six academics and practitioners in various fields. In the discussion, we raised themes and related topics such as government communication strategy, the role of celebrity endorsements in government organizations, the credibility and effectiveness of endorsers, the strategy for using endorsement to influence public opinion, and the use of propaganda as a strategy in government communication and political public relations.

Table 2. Participants' profile

\begin{tabular}{r|l|cll}
\hline No & Gender & Age & Field of Knowledge \\
\hline 1 & Male & 62 & Government Communication \\
2 & Male & 46 & Political Communication \\
3 & Male & 68 & Corporate Public Relations \\
4 & Male & 65 & Government Communication \\
5 & Female & 45 & Management \& Communication \\
6 & Female & 62 & Advertising \& Marketing \\
\cline { 2 - 3 } & & &
\end{tabular}

In terms of the government's communication strategy, particularly in dealing with COVID-19, the majority of participants perceived a fundamental shortcoming in the government's planning and implementation of its communication strategy. Four informants agreed that the government did not have a clear communication strategy for communicating public health programs. Furthermore, the presidential spokesperson is said to have had a little impact due to poor communication and persuasive abilities, and thus, worsening government communication. More importantly, nearly all participants agreed that a lack of cooperation between central and local government officials caused a damage to government legitimacy and public trust. These are the key elements we discovered that pose obstacles to government communication in its efforts to persuade the public to embrace government programs. Two participants, among others, presented their views, which were verified by the other participants as follows.
In my opinion, there is no coordination between sectoral communication and regional communication in the Jokowi's government communication. Each in its own way, and each allocates considerable funds for it. In substance, each one goes its own way and has happened until now, so when I say in the context of democracy, I haven't seen it yet - there is no government communication strategy based on a "bottom up" approach, which accommodates the interests of the community (Male, government communication practitioner, academics, 65).

If the government already has a good communication strategy or whatever strategy, then things like mismanagement and misleading information can be anticipated. But I believe that maintaining the reputation of the government and the image of the government is not as easy as maintaining the brand image (Female, 
academics and practitioner in advertising \& marketing, 62).

Following that, several informants questioned the abilities and understanding of government communication strategists on the employment and legitimacy of celebrity endorsements in government organizations. Given that governments are typically wellversed in propaganda methods, several participants questioned how well they understood the strategies and efficacy of celebrity endorsers in political public relations. A female participant, for example, felt that the government was only active in collaborating with influencers because they have a large number of followers. The government may overlook the fact that the impact of influencers is not just determined by the number of people who follow them.

She went on to say that while it is great for a firm to introduce or sell a product, the number of followers is critical. "However, when the government tries to market a policy, does it simply consider the number of social media followers? Do they also assess the trustworthiness of influencers? Is he capable or not? This appears to be what the administration has forgotten." (Female, academics in management \& communication, 45). However, a different view was expressed by another participant. He said that currently there has been a paradigm shift in government communication, and the government seems to be doing trial and errors.

Marketing and public relations play a far larger part in politics these days. Former President Yudhoyono is one of the leaders who pioneered the use of political public relations and political marketing in Indonesia. However, the situation has changed dramatically in the last ten years, and not only in Indonesia... Someone must be working behind the scenes. So, what is truly being done nowadays is propaganda in political public relations rather than political marketing. We can still discuss a lack of ethics and expertise, but we must also consider the government's use of propaganda (Male, academics in political communication, 46).

Furthermore, we found some variations of opinion among participants about the effectiveness of communication strategies involving the use of celebrity endorsements to impact public attitude and behavior toward vaccination programs. A female participant, for example, believed that celebrity endorsers would be useful if the objective is to raise vaccination awareness, because influencers have a large reach. Additionally, this is not just because he or she has a significant fan base, but also because they have the attractiveness of being noteworthy in the media. "However, if the purpose is to educate people about what the vaccination is used for, what the side effects of the vaccine are, and what the advantages are, it does not work. Hence, it depends on the goal." (Female, academics in management \& communication, 45). Similarly, other female participants stated that the public had become more educated and realized that it was simply an advertising if it was treated like that. "While public relations are distinct in that they employs a third-party approach. They used to use the mainstream media as endorsers when there weren't many social media users and influencers." She maintains:

Now, I believe it makes sense for them to employ endorsers as part of their communication plan. Because they may infer from their own communication experience that the third-party speaker is more trustworthy than the person saying it. But, without quantitative approach, it's difficult to determine whether something is beneficial or ineffective. What is the goal? It appears that the administration lacks a clear vision of its strategy, since everything appears to be dependent on reactive intuition or a guessing game (Female, academics in advertising \& marketing, 62).

To get a broader perspective, we also include some perspectives and opinions from other participants on this matter as follows.

If I were a government public communicator, I would research endorsement first. We must not take any shortcuts. If I look at it right now, the shortcut is already in place. For example, my colleague here mentioned the vaccination previously, so this is to make vaccine socialization easier; simply call Raffi! As a shortcut, that is correct (Male, practitioner and academics in government communication, 62).

I agree with my colleague earlier in this conversation that this endorsement is not 
very useful in politics, but it depends. I have never seen us fail to learn a lesson, as was learned from America. The teachings of sponsorship from everywhere are only used for entertainment - gathering the publicnot to influence the public or as stakeholders. In the US, they even had to hire a real spin doctor (Male, practitioner \& academics in corporate public relations, 68).

Finally, in terms of the use of propaganda in government communications, we found that some participants considered propaganda to be an important part of government communications. If the endorsement is associated with propaganda techniques, one female participant stated that this is actually a good phenomenon, either endorsements or influencers, as long as they are used because these are true opinion leaders. "As long as it's used properly, it's clear what the objective is, in my opinion, it's good for political communication, any kind of communication. That's fine." (Female, academics and practitioner in advertising \& marketing, 62).

In a different perspective, a male participant believed that current propaganda has been used with several other persuasion techniques so that there is an important difference between propaganda and other forms of communication which lies in psychological manipulation, and that it is much more powerful and almost a necessity nowadays in any government. Propaganda, he argues, is the lowest level of public relations strategy, but some organizational goals can be best achieved by propaganda. He maintains that propaganda is far more successful because it employs computational calculations. "The method of communicating with the public is top-down, which I will criticize if I use ethical lenses. So, to summarize, what the government has done with COVID and vaccinations is nothing more than public information" (Male, academics in political communication, 46).

Our findings in the group discussion above show that there are similarities to our previous findings which were verified by the participants. For example, the participants' concern about the lack of coordination of information between government departments in conveying information and public communications, thereby undermining government credibility and public trust. The informants also considered that propaganda in the government's communication strategy is a common and effective technique if it is well planned and proportionate. However, not all of the participants' opinions are in line with the theories described earlier. Some participants, for example, thought that choosing Raffi Ahmad as an endorser to help the public health initiative succeed was inadequate since Ahmad was famous and attractive but not trustworthy when it came to addressing health issues.

\section{Limitations}

Our study has at least two limitations. First, our research was only carried out with a qualitative approach so that our empirical data cannot prove and generalize the effectiveness of celebrity endorsement in government organizations without being corroborated by quantitative survey evidence. Second, due to limited resources, our study had a relatively small sample for group discussion, and we were also unable to verify the results with other group discussions with different socio-economic and educational levels. Apart from this, our findings have important implications for the development of a theoretical framework especially in analyzing celebrity endorsement in the political realm.

\section{Conclusion}

We have examined the harness of celebrity endorsements from two research designs, and our study offers a new theoretical framework for examining the effects of celebrity endorsements from the perspective of propaganda and political public relations. This paper presents and underlines several propaganda practices in the context of government public relations because they have similarities to each other, or contain almost the same meaning as the concepts and theories that examine celebrity endorsement. Our findings in interviews in group discussions are not completely in line with the theory used, thus further research is needed with a quantitative approach to prove the effectiveness of celebrity endorsement in public policy and in the political realm.

We believe that propaganda techniques in the modern era and in a democratic society are still relevant and effective in marketing and advertising, as well as in the government's public relations strategy. Finally, we argue that celebrity endorsement can be a viable alternative for incorporating into the government's communication strategy in order to meet the government's specific goals. 


\section{Acknowledgements}

The authors would like to thank all FGD participants for their valuable time and for expressing their opinions regarding the theme of this research, namely Ahmed Soeriawidjaja, Arif Susanto, Freddy Tulung, Magda Harahap, Nico Wattimena, and Yuliana Prasetyawati.

\section{References}

Ahmad, N. (2021). Presidential rhetoric in the COVID-19 pandemic era: Jokowi's Aristotelian rhetorical leadership models before and after implementation of semilock down policy. Jurnal Komunikasi Ikatan Sarjana Komunikasi Indonesia, 6(1), 72-85. https://doi.org/10.25008/jkiski.v6i1.538

Aljasir, S. (2019). Are classic theories of celebrity endorsements applicable to new media used by Arabs? A qualitative investigation of Saudi social media users. Journal of Creative Communications, 14(1), 15-30. https://doi.org/10.1177/09732586188226 08

Agustiansyah, Z. \& Mardhiyah, D. (2020). The influence of endorser credibility, brand credibility, and brand equity on the purchase intention in online shopping: The Instagram phenomenon (In R. Hurriyati, B. Tjahjono, A. G. Abdullah, Sulastri, \& Lisnawati. (Eds.). Advances in business, management and entrepreneurship: Proceedings of the 4th global conference on business management \& entrepreneurship (GCBME 4), 8 August 2019, Bandung, Indonesia. CRC Press.

Ayuni, D. M., \& Prasetyawati, Y. R. (2020). The influence of celebrity endorsement and the advertisement message towards Telkomsel's product awareness and its impact on the purchase intention. Petra International Journal of Business Studies, $\quad 3(2), \quad 110-119$. https://doi.org/10.9744/ijbs.3.2.110-119

Badan Pusat Statistik. (2021, Januari 21). Hasil Sensus Penduduk 2020. Diunduh dari https://www.bps.go.id/pressrelease/2021 /01/21/1854/hasil-sensus-penduduk2020.html

Bayuni, E. (2020 March 13). COVID-19: Mr. President, you need professional help. The Jakarta Post. Retrieved from https://www.thejakartapost.com/academi a/2020/03/13/covid-19-communicationpresident-jokowi-you-need-professionalhelp.html

Davies, C., \& Hobbs, M. (2020). Irresistible possibilities: Examining the uses and consequences of social media influencers for contemporary public relations. Public Relations Review, 46(5), 101983. https://doi.org/10.1016/j.pubrev.2020.10 1983

Dhani, R. (2018). Political public relations in Indonesia under the Yudhoyono presidency: Past developments and new formations (Doctoral dissertation). Murdoch University, Perth, Western Australia. Retrieved from https://researchrepository.murdoch.edu.a $\mathrm{u} / \mathrm{id} / \mathrm{eprint} / 42838 /$

Enke, N., \& Borchers, N. S. (2019). Social media influencers in strategic communication: A conceptual framework for strategic social media influencer communication. International Journal of Strategic Communication, 13(4), 261-277. https://doi.org/10.1080/1553118x.2019.1 620234

Farisa, F. C. \& Galih, B. (2020 April 6). LP3ES catat ada 37 pernyataan blunder pemerintah soal Covid-19. Kompas.com. Retrieved from https://nasional.kompas.com/read/2020/ 04/06/17522121/1p3es-catat-ada-37pernyataan-blunder-pemerintah-soalcovid-19? page $=$ all

Frankish, K. (2010). Dual-process and dualsystem theories of reasoning. Philosophy Compass, $\quad 5(10), \quad 914-926$. https://doi.org/10.1111/j.17479991.2010.00330.x

How to Detect Propaganda. (1938). Bulletin of the American Association of University Professors (1915-1955), 24(1), 49-55. http://www.jstor.org/stable/40219502

Joko Widodo [@jokowi]. ((2021 January 13). Tekanan darah saya diukur...[Photograph]. Instagram. https://www.instagram.com/p/CJE6m6BG0W/

Jowett, G., \& O'Donnell, V. (2015). Propaganda and persuasion (6th ed.). Sage Publications, Inc. 
Kahneman, D. (2011). Thinking, fast and slow. Farrar, Straus and Giroux.

Krueger, R. A., \& Casey, M. A. (2000). Focus groups: A practical guide for applied research (4th ed). Sage Publications Inc.

Leedy, P. D. \& Ormrod, J. E. (2021). Practical research: Planning and design. Pearson Education Limited.

Kemp, S. (2021, February 11). Digital 2021: Indonesia. Retrieved from https://datareportal.com/reports/digital2021-indonesia

McCracken, G. (1989). Who is the celebrity endorser? Cultural foundations of the endorsement process. Journal of Consumer Research, 16(3), 310-321. https://www.jstor.org/stable/2489512

Mookda, R., Khan, S. W., Intasuwan, S., \& Chotchoung, S. (2020). The effect of celebrity endorsement on consumer purchase intention: The mediating role of brand loyalty. International Journal of Scientific and Research Publications (IJSRP), 10(06), 1016-1021. https://doi.org/10.29322/ijsrp.10.06.2020 .p102123

Moloney, K. (2006). Rethinking public relations: $P R$ propaganda and democracy. Routledge

Nabila, M. (2021). Indonesia COVID-19 task force statement framing in September November 2020. Jurnal Komunikasi Ikatan Sarjana Komunikasi Indonesia, 6(1), 149-160. https://doi.org/10.25008/jkiski.v6i1.505

O'Regan, V. R. (2014). The celebrity influence: Do people really care what they think? Celebrity Studies, 5(4), 469-483. https://doi.org/10.1080/19392397.2014.9 25408

Pangestika, D. (2020, March 14). 'We don't want people to panic': Jokowi says on lack of transparency about COVID cases. The Jakarta Post. Retrieved from https://www.thejakartapost.com/news/20 20/03/13/we-dont-want-people-to-panicjokowi-says-on-lack-of-transparencyabout-covid-cases.html.

Penney, J. (2018). Young people as political influencers on social media. Proceedings of the 9th International Conference on Social Media and Society. https://doi.org/10.1145/3217804.321794

4

Pusparisa, Y. \& Mutia, A. (2018, June 28). Masyarakat Indonesia paling banyak akses berita dari media daring [Indonesian people have the most access to news from online media]. Katadata.com. Retrieved from https://databoks.katadata.co.id/datapubli sh/2021/06/28/masyarakat-indonesiapaling-banyak-akses-berita-dari-mediadaring

Ramadhan, A. \& Meiliana, D. (2020 August 20). ICW catat pemerintah telah belanjakan Rp 1,29 triliun untuk aktivitas digital, termasuk bayar 'influencer'. Kompas.com. Retrieved from https://nasional.kompas.com/read/2020/ 08/20/14204811/icw-catat-pemerintahtelah-belanjakan-rp-129-triliun-untukaktivitas-digital?page $=2$

Raffi Ahmad [@raffinagita1717]. (2021a, January 13). Bismillah [Photograph]. Instagram.

https://www.instagram.com/p/CJB5HDsOE3/

Raffi Ahmad [@raffinagita1717]. (2021b, January 13). Alhamdulillah vaksin [Video]. Instagram. https://www.instagram.com/p/CJ$71 \mathrm{WbnDqV} /$

Raffi Ahmad [@raffinagita1717]. (2021c, January 13). Alhamdulillah hari ini Vaksin Perdana bersama Pa @jokowi [Photograph]. Instagram. https://www.instagram.com/p/CJO0H_M8T5/

Raffi Ahmad [@raffinagita1717]. (2021d, January 13). Raffi with TNI commander and Chief of Police [Photograph]. Instagram.

https://www.instagram.com/p/CJHYkosNLO/

Raffi Ahmad [@raffinagita1717]. (2021e, January 27). Alhamdulillah Vaksin Tahap 2 sudah berjalan lancar [Photograph]. Instagram. https://www.instagram.com/p/CKiGWp $\mathrm{SsBeU} /$

Rans Entertainment (2021a, January 13). Ini rasanya vaksin COVID 19 bareng pak presiden [Video]. You Tube. 
https://www.youtube.com/watch? $v=15 \mathrm{~h}$ UXSp-eYU

Rans Entertainment (2021b, January 23). Raffi Ahmad disuntik vaksin [Video]. You Tube.

https://www.youtube.com/watch? $v=s b j 2$ 6_DZjtQ

Rans Entertainment (2021c, January 27). Raffi dipanggil pak Jokowi dan vaksin ke 2!! [Video]. You Tube. https://www.youtube.com/watch?v=60YM7A2g_I\&t=136s

Riefky, Hutasoit, I. R., Nopiyanto, A. M., Nugrahani, H. S., \& Zulkarnain, R. A. (2021). Growing public distrust towards the Indonesian government for lack of response to COVID-19 outbreak. IOP Conference Series: Earth and Environmental Science, 716(1), 012072. https://doi.org/10.1088/17551315/716/1/012072

Sanders, K. (2020). Government communication and political public relations. In J. Strömbäck \& S. Kiousis (Eds.). Political Public Relations Concepts, Principles, and Applications. Routledge.

Sari, H. P. \& Meiliana, D. (2020 February 26). Pemerintah anggarkan Rp 72 Miliar untuk influencer, Fadli Zon: Ini cara-cara amatiran. Kompas.com. Retrieved from https://nasional.kompas.com/read/2020/ 02/26/18234821/pemerintah-anggarkanrp-72-miliar-untuk-influencer-fadli-zonini-cara-cara

Schimmelpfennig, C., \& Hunt, J. B. (2019). Fifty years of celebrity endorser research: Support for a comprehensive celebrity endorsement strategy framework. Psychology \& Marketing, 37(3), 488505. https://doi.org/10.1002/mar.21315

Salahudin, Nurmandi, A., Sulistyaningsih, T., Lutfi, M., \& Sihidi, I., T. (2020). Analysis of government official twitters during Covid-19 crisis in Indonesia. Talent Development \& Excellence 12(1), 3899$3815 . \quad$ Retrieved from https://iratde.com/index.php/jtde/article/ view/1343

Setiawana, A., Nurmandi, A., Purnomo, E. P., \& Muhammad, A. (2021). Disinformation and miscommunication in government communication in handling COVID-19 pandemic. Webology, 18(1), 203-218, doi: 10.14704/WEB/V18I1/WEB18084

Strömbäck, J. \& Kiousis, S. (Eds.) (2020). Political public relations: Concepts, principles, and applications (2nd Edition). Routledge.

Viswanathan, V., \& Jain, V. (2013). A dualsystem approach to understanding "Generation Y" decision making. Journal of Consumer Marketing, 30(6), 484-492. https://doi.org/10.1108/jcm-072013-0649

Windarsih, A. (2021). Public communication conflicts between the central government and the DKI Jakarta government in handling the COVID-19 pandemic. Proceedings of the International Conference on Social Science, Political Science, and Humanities (ICoSPOLHUM 2020). https://doi.org/10.2991/assehr.k.210125. 012 